\title{
Pemberdayaan Cabang Aisyiyah Ngampilan Yogyakarta melalui Literasi "Media Sehat"
}

\section{Empowerment of Yogyakarta Ngampilan Aisyiyah Branch through "Healthy Media" Literacy}

\section{Adhianty Nurjanah ${ }^{*}$ \\ Dyah Mutiarin ${ }^{2}$}

1Department of Communication Science, Universitas Muhammadiyah Yogyakarta, Bantul, Special Region of Yogyakarta, Indonesia

2Department of Public Administration, Universitas Muhammadiyah Yogyakarta, Bantul, Special Region of Yogyakarta, Indonesia

email: adhianty@umy.ac.id

\section{Kata Kunci}

Hoax

Literasi

Pemberdayaan

Keywords:

Hoax

Literacy

Empowerment

Received: June 2020

Accepted: November 2020

Published: December 2020

\begin{abstract}
Abstrak
Saat ini kita hidup ditengah derasnya perkembangan sistem komunikasi dan sesaknya media yang pada dasarnya membuat setiap orang harus waspada pada setiap informasi yang disampaikan. Pemberitaan bohong atau hoax menjadi fokus perhatian terutama di media online. Hoax merupakan informasi yang direkayasa untuk menutupi informasi sebenarnya. Berdasarkan hasil wawancara dan observasi Tim Pengabdian Masyarakat dengan mitra bahwa anggota dan pengurus PCA secara aktif sebagai konsumen media massa terutama TV dan media internet yaitu WA sebagai media informasi sehari-hari. Dalam kegiatan kepengurusannya belum pernah dilakukan literasi media padahal literasi media merupakan kebutuhan masyarakat yang berdaya dan melek informasi. Dengan demikian melalui kegiatan pengabdian masyarakat ini akan dilakukan Pengabdian Masyarakat berupa Pemberdayaan Cabang Aisyiyah Ngampilan Melalui Literasi Media Sehat. Metode yang dilaksanakan oleh Tim pengabdian masyarakat ini adalah workshop terkait pentingnya literasi media dalam menghadapi Hoax, pendampingan literasi media dalam menghadapi Hoax, workshop "Tabayun terhadap informasi agar Cerdas Sebagai Insan yang Melek Media" berbasis Digital, pembuatan buku panduan Literasi Media Sehat, Cerdas Sebagai Insan yang Melek Media menghadapi Hoax", pemberian fasilitas kantor Cabang Aisyiyah Ngampilan yang dapat dipergunakan untuk mendukung kegiatan kepengurusan Cabang Aisyiyah Ngampilan Yogyakarta. Hasil pengabdian masyarakat berbasis Muhammadiyah ini adalah meningkatnya kemampuan pengurus dan anggota khususnya terkait literasi media sehat dalam menghadapi Hoax.
\end{abstract}

\begin{abstract}
We currently live amid the rapid development of communication systems and the media's tightness, which makes everyone aware of any information conveyed. The coverage of lies or hoaxes is the focus of attention, especially in online media. Hoax is information that is engineered to cover up real information. Based on the Community Service Team's interviews and observations with partners, PCA members and administrators are acting as consumers of mass media, especially TV and internet media, namely WA, as daily information media. In its management activities, media literacy has never been carried out, even though media literacy needs an empowered and information literate society. Thus, Community Service will be carried out through this community service activity in the form of Empowerment of Aisyiyah Ngampilan Branches through Healthy Media Literacy. The method carried out by the community service team is workshops related to the importance of media literacy in dealing with hoaxes; media literacy assistance in dealing with hoaxes; digital-based "Tabayun on information to be smart as a media literate person"; making a guide book for Healthy Media Literacy; Smart As Media literate individuals face hoaxes"; providing facilities for the Aisyiyah Ngampilan Branch office that can be used to support management activities of the Aisyiyah Ngampilan Yogyakarta Branch. This Muhammadiyah-based community service is the increased ability of the board and members, especially related to healthy media literacy in dealing with hoaxes.
\end{abstract}




\section{PENDAHULUAN}

Saat ini kita hidup ditengah derasnya perkembangan sistem komunikasi dan sesaknya media (media-saturated world) yang pada dasarnya membuat setiap orang harus waspada pada setiap informasi yang disampaikan. Kita sebagai masyarakat dalam menyikapi kondisi ini harus berhati-hati dan tabayun akan informasi yang disampaikan melalui radio, surat kabar, televisi maupun internet. Media sosial muncul dalam media baru dan saat ini mayoritas masyarakat mengkonsumsi media sosial. Dalam hal ini media sosial memampukan kita untuk dapat bertukar informasi dengan semua orang yang merupakan sesama pengguna media tersebut (Sebayang, 2019).

Menurut Nasrullah (2015), media sosial adalah medium di internet yang memungkinkan pengguna merepresentasikan dirinya maupun berinteraksi, bekerjasama, berbagi, berko- munikasi dengan pengguna lain, dan membentuk ikatan sosial secara virtual. Adanya fitur share, like, hashtag, trending topic, di media sosial tidak dapat dipungkiri telah mempengaruhi masyarakat untuk ikut terlibat aktif sebagai penyebar sekaligus konsumen informasi yang disampaikan melalui media sosial tersebut. Melalui fitur tersebut, berita dan informasi dapat dibagikan secara viral: tersebar luas dan terjadi dalam waktu singkat layaknya wabah penyakit yang disebarkan oleh virus (Fatmawati et al., 2020).

Berdasarkan hasil studi Berger dan Milkman (Thompson, 2014) menunjukkan bahwa berita-berita yang dibagikan secara viral melalui media sosial adalah berita yang mampu membangkitkan emosi positif atau negatif yang sangat kuat (high-arousal emotions). Meski demikian, disadari pula bahwa pengguna media sosial non Jurnalis umumnya tidak paham pentingnya akurasi, sebelum menyebarkan tidak melakukan verifikasi, tabayun terhadap kebenaran informasi tersebut, serta tidak memiliki pemahaman yang cukup untuk memahami etika jurnalisme dan hukum media daring saat membagikan informasi di media sosial (Fadli, 2018). Saat ini, pemberitaan bohong atau palsu (hoax) menjadi fokus perhatian terutama di media online. Hoax merupakan informasi yang direkayasa untuk menutupi informasi sebenarnya. Dengan kata lain hoax juga bisa diartikan sebagai upaya penutarbalikan fakta menggunakan informasi yang seolah-olah meyakinkan tetapi tidak dapat diveri kasi kebenarannya. Hoax juga bisa diartikan sebagai tindakan mengaburkan informasi yang sebenarnya, dengan cara membanjiri suatu media dengan pesan yang salah agar bisa menutupi pesan yang benar. Tujuan dari hoax yang disengaja adalah membuat masyarakat merasa tidak aman, tidak nyaman, dan kebingungan. Dalam kebingungan, masyarakat akan mengambil keputusan yang lemah, tidak meyakinkan, dan bahkan salah (Gumilar et al., 2017; Zakirah, 2020).

Dalam hal ini sangat diperlukan penguatan pengetahuan dan pemahaman kepada masyarakat yang mengkonsumsi media tersebut melalui sebuah upaya memahami media yang lebih baik yaitu kegiatan literasi media. Kemudahan mengakses informasi tak akan banyak artinya bila kemudian tidak diimbangi dengan literasi media. Persiapan itu diperlukan karena media massa bukan hanya melaporkan apa yang terjadi melainkan juga mempengaruhi khalayaknya. Literasi media merupakan upaya pembelajaran bagi khalayak media sehingga menjadi khalayak yang berdaya hidup di tengah dunia yang disebut dunia sesak-media (media saturated) (Iriantara, 2009).

Dalam konteks ini, pendidikan media adalah salah satu upaya untuk mencapai melek media masyarakat. Literasi media dapat dipandang sebagai salah satu upaya memberi kekuatan dan titik acuan intelektual yang diperlukan untuk memahami dunia disekitarnya. Dalam kaitannya dengan literasi media, konsep 
pendidikan ini mempersiapkan masyarakat untuk bisa hidup dalam dunia sesak- media (Purba, 2015).

Menurut National Leadership Conference on Media Education menyatakan literasi media sebagai kemampuan untuk mengakses, mengevaluasi dan mengkomunikasikan pesan dalam pelbagai bentuknya. Sementara itu, Pasal 52 Undang-undang No. 32/2003 tentang Penyiaran memaknai literasi media sebagai "kegiatan pembelajaran untuk meningkatkan sikap kritis masyarakat" (Iriantara, 2009). Pada sisi lain, pendidikan media merupakan bentuk pemberdayaan khalayak media. Hal ini sesungguhnya terkait dengan tujuan pendidikan media yang tidak lagi bertujuan untuk melindungi khalayak media sebagai konsumen produk yang dihasilkan industri media, tetapi juga mempersiapkan khalayak sebagai konsumen media untuk hidup di dunia yang dunia sosialnya sangat bergantung pada media massa. Karena itu, salah satu prinsip dalam pendidikan media atau literasi media adalah memberdayakan khalayak. Disebut memberdayakan, karena dalam pandangan Brow (Iriantara 2009), “literasi media menjadi kompas baru dalam mengarungi dunia media. Karena, dalam penilaian Brow, " bila orang tidak diberdayakan, maka orang akan menjadi korban media."

Tujuan literasi media adalah memberi kita kontrol yang lebih besar atas interpretasi karena semua pesan media merupakan hasil konstruksi. Berkenaan dengan pemberdayaan khalayak media untuk membangun khalayak yang berdaya tersebut, kita akan kembali melihat tujuan dan aliran pendidikan media untuk mencapai melek-media. Mempelajari literasi media erat kaitannya dengan peningkatan kemampuan peserta untuk memahami, menganalisis isi media.

Elemen-elemen literasi media menurutSilverblatt (1995), diantaranya: (1) kesadaran akan pengaruh media terhadap individu dan sosial; (2) pemahaman akan proses komunikasi massa; (3) pengembangan strategi untuk menganalisis dan mendiskusikan pesan media; (4) kesadaran bahwa isi media adalah teks yang menggambarkan kebudayaan dan diri kita sendiri pada saat ini; dan (5) mengembangkan kesenangan, pemahaman, dan penghargaan terhadap isi media.

Dalam hal ini upaya yang kami lakukan yaitu dengan melaksanakan Pengabdian Kepada Masyarakat berbasis Persyarikatan Muhammadiyah. Dengan tujuan untuk meningkatkan kompetensi literasi media yang sehat dalam menghadapi hoax. Kegiatan ini dilaksanakan dengan memberikan contoh-contoh kontemporer dan pemaparan terkait risiko-risiko dari ketersebaran hoax. Sebagai Ibu yang beperan mendidik generasi muda diharapkan dapat mempergunakan media dengan bijak, apalagi dengan semakin berkembangnya informasiinformasi palsu yang dapat menyesatkan dan membingungkan. Selain itu ibu pengurus dan anggota Cabang Aisyiyah Ngampilan diharapkan dapat cerdas memilih informasi yang diterimanya melalui media sosial, mereka pun harus faham bagaimana menyebarkan konten yang ada di media sosial.

Mitra pengabdian berbasis Persyarikatan Muhammadiyah (PPM-Muh) kali ini adalah Pimpinan Cabang Aisyiyah Ngampilan yang berlokasi di Ngampilan Yogyakarta. Adapun Pimpinan Cabang Aisyiyah Ngampilan memiliki lahan dakwah di setiap ranting yaitu terdapat 7 ranting sebagai berikut:

1. PRA Patuk

2. PRA Purwodiningratan

3. PRA Ngadiwinatan

4. PRA Ngampilan

5. PRA Suronatan

6. PRA Notoprajan

7. PRA Serangan

Berdasarkan hasil wawancara dan observasi Tim Pengabdian Masyarakat dengan mitra bahwa anggota 
dan pengurus PCA secara aktif sebagai konsumen media massa terutama TV dan media internet yaitu WA sebagai media informasi sehari-hari. Dalam kegiatan kepengurusannya belum pernah dilakukan literasi media padahal literasi media merupakan kebutuhan masyarakat yang berdaya dan melek informasi. Dengan demikian melalui kegiatan pengabdian masyarakat ini akan dilakukan Pengabdian Masyarakat berupa Pemberdayaan Cabang Aisyiyah Ngampilan Melalui Literasi Media Sehat.

Dari diskusi yang dilakukan oleh Tim Pengabdian masyarakat ini dengan Pihak Pimpinan Cabang Aisyiyah Ngampilan Yogyakarta maka pilihan prioritas permasalahan sebagai berikut:

1. Peningkatan wawasan dan pengetahuan terkait literasi media yang sehat bagi anggota dan pengurus Pimpinan Cabang Aisyiyah Ngampilan. Hal ini didasarkan pada pertimbangan bahwa mereka adalah seorang ibu di keluarga dimana memiliki peran penting dalam pendidikan anak dan masih kurangnya pemahaman dalam menghadapi arus informasi terutama hoax di sekitar kita.

2. Belum adanya buku panduan terkait literasi media yang sehat dalam menghadai Hoax yang dapat dijadikan bahan referensi sehingga menambah pemahaman dan pengetahuan anggota dan pengurus Pimpinan Cabang Aisyiyah Ngampilan.

3. Masih minimnya fasilitas kantor Cabang Aisyiyah Ngampilan yang dapat dipergunakan untuk mendukung kegiatan kepengurusan Cabang Aisyiyah Ngampilan Yogyakarta.

\section{METODOLOGI}

Pada pelaksanaan pengabdian kepada PCA Ngamilan Yogyakarta, alat yang digunakan yakni berupa bantuan kursi dan meja sebagai pendukung kinerja mitra Pemberdayaan Cabang Aisyah Ngampilan, sedangkan bahan yang digunakan sebagai bentuk pemberdayaan yakni materi literasi hoax dan buku literasi media sehat. Adapun metode yang akan dilaksanakan oleh Tim pengabdian masyarakat ini adalah sebagai berikut:

1. Workshop terkait pentingnya literasi media dalam menghadapi Hoax

2. Pendampingan literasi media dalam menghadapi Hoax

3. Workshop "Tabayun terhadap informasi agar Cerdas Sebagai Insan yang Melek Media" berbasis Digital,

4. Pembuatan buku panduan Literasi Media Sehat, Cerdas Sebagai Insan yang Melek Media menghadapi Hoax",

5. Pemberian fasilitas kantor Cabang Aisyiyah Ngampilan yang dapat dipergunakan untuk mendukung kegiatan kepengurusan Cabang Aisyiyah Ngampilan Yogyakarta

Adapun langkah dalam proses menjalankan program sebagai berikut

1. Penilaian awal (initial assessment) permasalahan Identifikasi permasalahan dilakukan melalui kegiatan FGD baik dengan Ketua PCA maupun bersama perwakilan anggota PCA Ngampilan. Keluaran (output) dari kegiatan ini adalah pemetaan permasalahan penerimaan informasi melalui media berupa Hoax.

2. Peningkatan Kesadaran dan Pengetahuan

Peningkatan kesadaran dan pengetahuan tentang literasi media dan menjadi insan yang melek media tentunya perlu diberikan baik kepada Pengelola PCA Ngampilan maupun Masyarakat agar timbul kesadaran dan pengetahuan tentang lierasi media dan emnghindari Hoax. Peningkatan kesadaran dan pengetahuan dilakukan melalui workshop dan studi banding. Keluaran dari tahap ini adalah tersusunnya 
Buku Panduan Literasi Media Sehat, Cerdas Sebagai Insan yang Melek Media Menghadapi Hoax.

3. Pendampingan dan Pemberdayaan Pengurus PCA Ngampilan

Pendampingan dan pemberdayaan dilakukan agar nilai-nilai kesadaran tentang literasi media dan menjadi insan yang melek media melalui berbagai pelajaran yang kemudian diaplikasikan dalam kehidupan sehari-hari. Pendampingan dan pemberdayaan dilakukan dengan melakukan workshop berbasis Digital dan pendampingan “Tabayun terhadap informasi agar Cerdas Sebagai Insan yang Melek Media".

\section{HASIL DAN PEMBAHASAN}

\section{Forum Group Discussion}

Forum Group Discussion (FGD) memiliki tujuan untuk mengidentifikasi lebih mendetail terkait permasalahan literasi media di PCA Ngampilan. FGD adalah hasil dari diskusi antar pengurus PCA Ngampilan dan Tim Pengabdian. Adapun output dari FGD ini untuk menjadi rancangan penyusunan buku panduan Literasi Media Sehat, Cerdas Sebagai Insan yang Melek Media Menghadapi Hoax sebagaimana ditunjukkan pada Gambar 1.

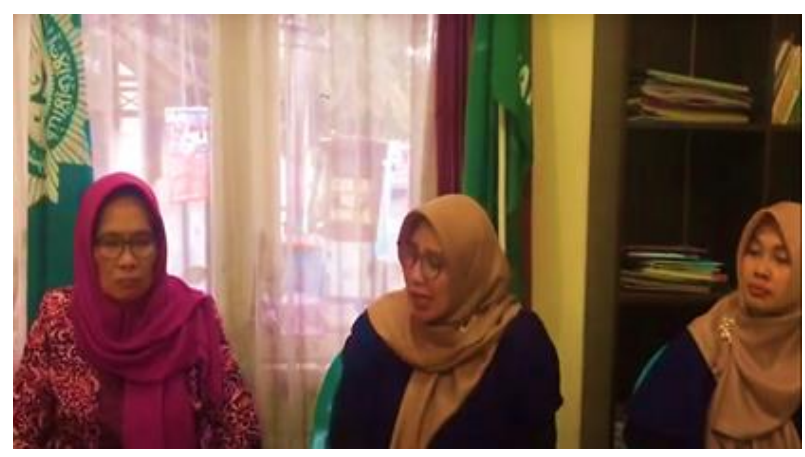

Gambar 1. Forum Group Discussion

\section{Workshop}

Workshop ini dilakukan untuk meningkatkan kesadaran dan pengetahuan dalam literasi media khususnya untuk menghadapi hoax. Pada proses workshop, Tim Pengabdian yang merupakan Dosen Ilmu Komunikasi dan Dosen Ilmu Pemerintahan UMY adalah narasumber yang berbagi pengetahuan kepada Pengurus PCA Ngampilan untuk menambah wawasan dalam berkomunikasi baik menerima informasi maupun menyebarkan informasi. Pada kegiatan ini diharapkan akan meningkatnya pemahaman terkait pentingnya literasi media dan menjadi insan yang melek media bagi pengurus dan anggota PCA Ngampilan seperti ditunjukkan pada Gambar 2.

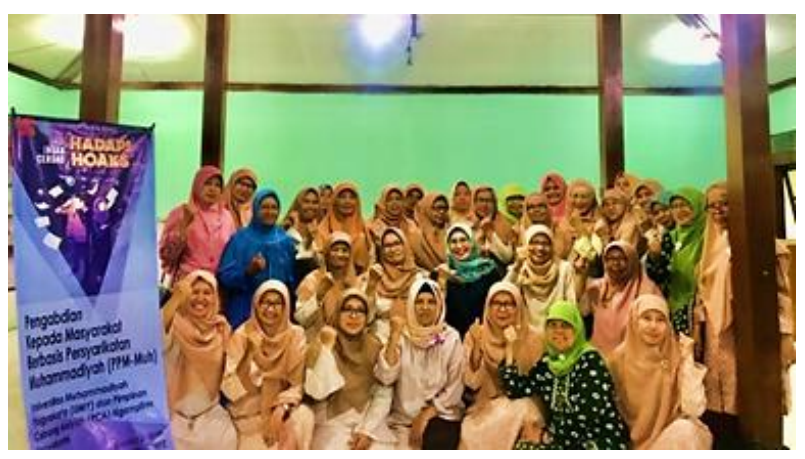

Gambar 2. Workshop Menghadapi Hoax

Pada saat workshop, tim membuat post-test dan pre-test terkait informasi media dan apa yang pengurus PCA Ngampilan tahui tentang hoax. Hal tersebut berguna untuk mengukur dan melihat kemampuan peserta yang menjadi target workshop sehingga setelah adanya workshop ini wawasan serta skill peserta dapat bertambah dan meningkat sesuai dengan apa yang menjadi tujuan workshop ini dibuat khususnya terkait literasi media.

Pada sebelum dilakukannya workshop, dilakukan pretest dimana wawasan mengenai informasi dan berkomunikasi di media sekarang sangat minim, dan tidak pernah mengetahui informasi terkait literasi hoax, karena belum pernah sekalipun pendapatkan literasi terkait media. Oleh karenanya hasil rata - rata presentase pengetahuan pengurus PCA Ngampilan berada di angka $8 \%$. 
Setelah mendapatkan materi workshop, dilakukan kembali post-test untuk mengetahui dan mengukur tingkat pemahaman peserta workshop terkait literasi media. Post-test yang dilakukan terjadi peningkatan wawasan mengenai informasi, media, dan hoax. Banyak diantara peserta mengakui menjadi sangat terbantu dengan adanya informasi dan workshop informasi ini. Mereka mengatakan bahwa workshop ini sangat bermanfaat dan membuka wawasan mereka sebelum menyebarkan informasi, dan lebih berhati - hati dengan cara filter terlebih dahulu informasi yang akan di sebarkan kepada orang lain, dan hasil post-test setelah dilakukannya workshop meningkat menjadi $88 \%$, artinya ada terdapat peningkatan yang signifikan yakni terjadi peningkatan sebanyak $80 \%$ dan dinilai efektif untuk menciptakan perubahan sosial dalam literasi media terkait hoax.

\section{Pengadaan Buku Panduan Literasi Media Sehat}

Pembuatan Buku Panduan Literasi Media Sehat merupakan upaya dari Tim Pengabdian UMY agar ilmu dan informasi terkait literasi media tetap akan diaplikasikan oleh Pengurus PCA Ngampilan sebagaimana ditunjukkan pada Gambar 3. Penyusunan buku ini dilatarbelakangi maraknya hoax yang menyebar dan merupakan informasi yang direkayasa untuk menutupi informasi sebenarnya. Dengan kata lain hoax sebagai upaya pemutarbalikan fakta menggunakan informasi yang seolah-olah menyakinkan namun tidak dapat diverifikasi kebenarannya. Buku ini membahas tentang mengapa kita membutuhkan literasi media, apa itu hoax dan jenis - jenisnya, hoax di sekitar kita, serta trik agar kita waspada terhadap hoax dan hal hal apa saja yang dapat kita lakukan agar kita menjadi insan yang cerdas dan melek media serta bijaksana dalam menghadapi hoax.

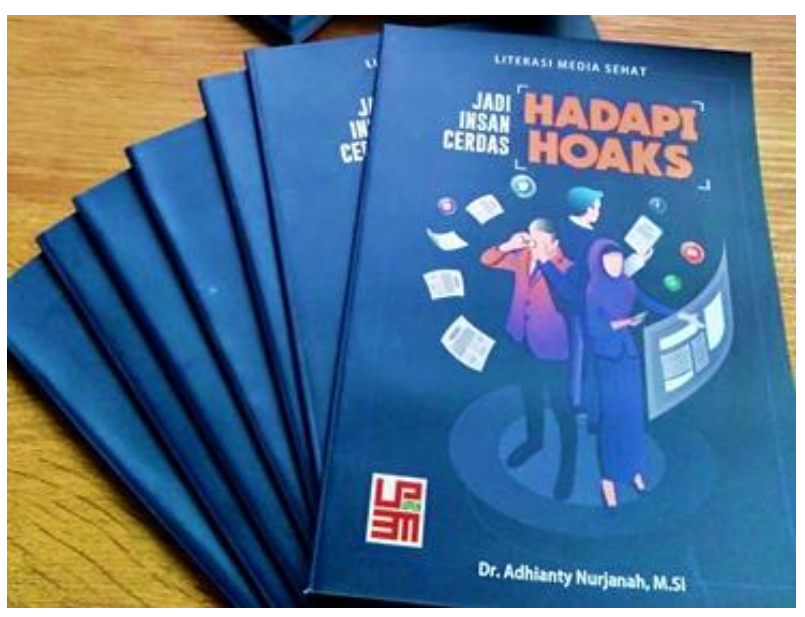

Gambar 3. Buku Literasi Media Sehat, Menjadi Insan Cerdas Hadapi Hoax

\section{Pengadaaan Barang Hibah}

Selain memberikan workshop untuk meningkatkan pengetahuan Pengurus PCA Ngampilan terkait literasi media, Tim Pengabdian UMY turut memberikan pengadaan dan penambahan barang. Hal ini untuk memfasilitasi kantor Aisyiyah untuk mendukung administrasi kepengurusan PCA Ngampilan.

\section{KESIMPULAN}

Program Pengabdian Masyarakat skema Perserikatan Muhammadiyah (PPM-Muhammadiyah) ini telah berhasil melakukan Forum Group Discussion untuk mengidentifikasi lebih mendetail terkait permasalahan literasi media khususnya terkait menyaring informasi untuk terhindar dari hoax. Sehingga komunikasi pada organisasi PCA dapat sesuai dan berbagi pengetahuan maupun informasi yang benar dan dapat dipertanggungjawabkan. Selain itu telah terbentuknya Buku Panduan Literasi Media Sehat, Menjadi Insan Cerdas Hadapi Hoax, hal ini dapat meningkatkan komitmen serta bertujuan untuk mensosialisasikan literasi media dalam menghadapi hoax, sehingga PCA Ngampilan kedepannya dapat menjadi pilot project (percontohan) dan menyebarkan informasi yang baik kepada PCA yang lainnya maupun kepada masyarakat 
disekitarnya. Dalam mendukung pengetahuan dan menambah wawasan Pengurus PCA Ngampilan maka dilakukan pula workshop terkait Literasi Media Sehat sehingga penguatan pengetahuan Pengurus PCA Ngampilan dapat bertambah dengan luas terkait media dan menghindari hoax yang mana memiliki peningkatan hingga $80 \%$. Saran yang dapat diberikan yakni perlunya peningkatan kapasitas bagi pengurus PCA Ngampilan agar ketika menyampaikan literasi media yang sama seperti Tim Pengabdian sampaikan akan memiliki pesan yang sama yakni untuk meliterasi media dan bagaimana yang harus dilakukan ketika menghadapi suatu hoax. Sehingga dapat terbentuk peningkatan komitmen pengurus dan masyarakat dalam meningkatkan kualitas menyebarkan dan menerima informasi sehingga dapat menurunkan tingginya angka persebaran hoax.

\section{UCAPAN TERIMA KASIH}

Terima kasih kepada LP3M Universitas Muhammaidyah Yogyakarta sebagai lembaga yang mensupport kegiatan Program Pengabdian Masyarakat Berbasis Perserikatan Muhammadiyah (PPMMuhammadiyah) serta penghargaan sebesar - besarnya kepada pihak PCA Ngampilan Yogyakarta yang telah berpartisipasi dalam kegiatan Pengabdian yang dilakukan.

\section{REFERENSI}

Fadli, A. 2018. Etika Dan Tanggung Jawab Jurnalis (Studi Pemberitaan Hoax Melalui Media Online Di Kota Makassar). Jurnal Jurnalisa : Jurnal Jurusan Jurnalistik. 4(2):181-195. https://doi.org/10.24252/jurnalisa.v4i2.6893

Fatmawati, K., Zuthfiyah, R., Kafa, R.A. 2020. Demokrasi Dalam Penggunaan Media Sosial (Studi Kasus Postingan Di Twitter Tentang Anggaran Lem Aibon Pemerintah Provinsi Dki Jakarta).
JMAN (Jurnal Mahasiswa Administrasi Negara). 4(1):14-25.

Gumilar, G., Adiprasetio, J., Maharani, N. 2017. Literasi Media: Cerdas Menggunakan Media Sosial Dalam Menanggulangi Berita Palsu (Hoax) Oleh Siswa SMA. Jurnal Pengabdian Kepada Masyarakat. 1(1):35-40.

Iriantara, Y. 2009. Literasi Media: Apa, Mengapa, Bagaimana. Bandung: Simbiosa Rekatama Media

Nashrullah, R. 2015. Media sosial Perspektif Komunikasi ,Budaya, dan Sosioteknologi. Bandung: Simbiosa Rekatama Media

Purba, R. 2015. Tingkat Literasi Media Pada Mahasiswa (Studi Deskriptif Pengukuran Tingkat Literasi Media Berbasis Individual Competence Framework Pada Mahasiswa Departemen Ilmu Komunikasi USU). Jurnal Ilmu Komunikasi Flow. 2(9):1-10.

Sebayang, E.R. 2019. Mempertahankan Identitas Nasional Di Era Digital. Rangkiang: Jurnal Pengabdian Pada Masyarakat. 1(2):107-110. https://doi.org/10.22202/rangkiang.2019.vli 2.3778

Silverblatt, A. 1995. Media Literacy: Keys to Interpreting Media Messages. London: Praeger

Thompson, D. 2014. The Facebook Effect on the News. The Atlantic. https://www.theatlantic.com/business/arch ive/2014/02/the-facebook-effect-on-thenews/283746/

Zakirah, D.M.A. 2020. Pengaruh Hoax di Media Sosial Terhadap Preferensi Sosial Politik Remaja di Surabaya. Jurnal Mediakita : Jurnal Komunikasi dan Penyiaran Islam. 4(1):1-10. https://doi.org/10.30762/mediakita.v4i1.244 6 